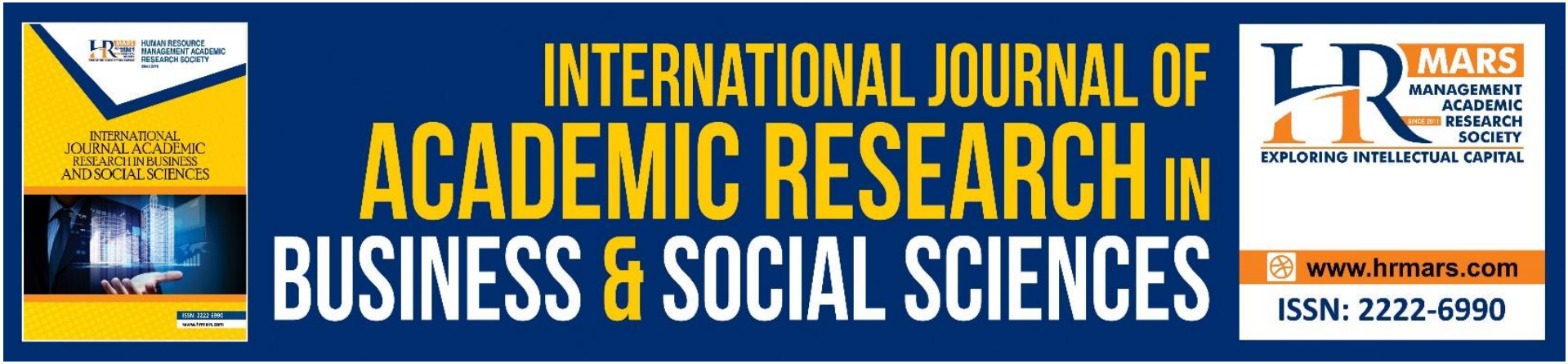

\title{
Fraud Schemes and Fraudulent Accountants Prosecution
}

Osagioduwa Lucky Ogbomo, Ojiakor ljeoma P., EseTheresa Esenohor, Odiachi Laurretta

To Link this Article: http://dx.doi.org/10.6007/IJARBSS/v12-i1/12126 DOI:10.6007/IJARBSS/v12-i1/12126

Received: 14 November 2021, Revised: 21 December 2021, Accepted: 24 December 2021

Published Online: 16 January 2022

In-Text Citation: (Osagioduwa et al., 2022)

To Cite this Article: Osagioduwa, L. O., Ojiakor, I. P., Esenohor, E., \& Odiachi, L. (2022). Fraud Schemes and Fraudulent Accountants Prosecution. International Journal of Academic Research in Business and Social Sciences, 12(1), 1143-1169.

Copyright: (c) 2022 The Author(s)

Published by Human Resource Management Academic Research Society (www.hrmars.com)

This article is published under the Creative Commons Attribution (CC BY 4.0) license. Anyone may reproduce, distribute, translate and create derivative works of this article (for both commercial and non0-commercial purposes), subject to full attribution to the original publication and authors. The full terms of this license may be seen at: http://creativecommons.org/licences/by/4.0/legalcode

Vol. 12, No. 1, 2022, Pg. $1143-1169$

http://hrmars.com/index.php/pages/detail/IJARBSS

JOURNAL HOMEPAGE

Full Terms \& Conditions of access and use can be found at http://hrmars.com/index.php/pages/detail/publication-ethics 


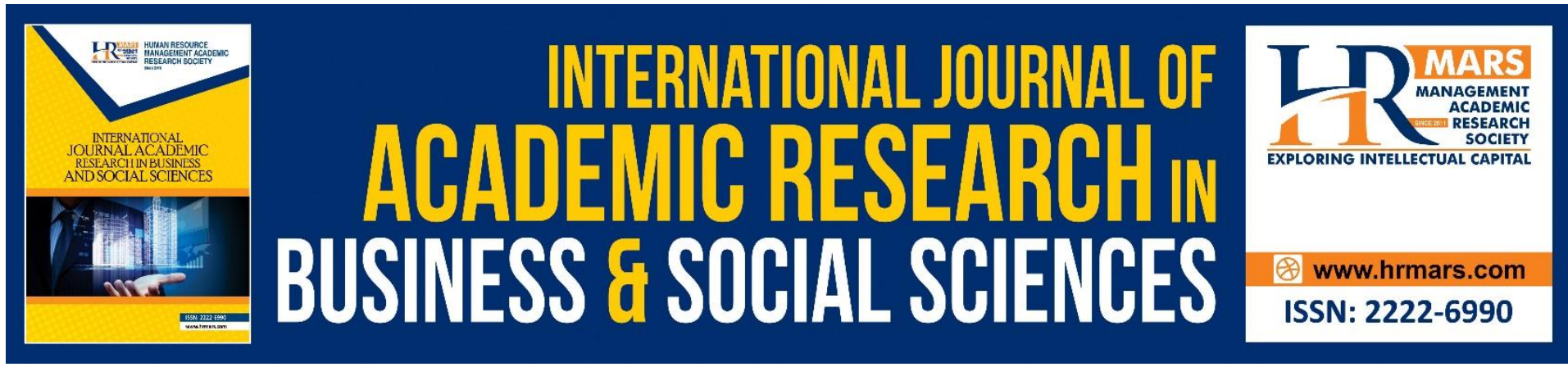

\title{
Fraud Schemes and Fraudulent Accountants Prosecution
}

\author{
Osagioduwa Lucky Ogbomo \\ Department of Accountancy, Lighthouse Polytechnic, Evbuorbanosa, Edo State, Nigeria. \\ Email: Osaslucky321@gmail.com
}

Ojiakor ljeoma P. (PhD)

Deparment of Accountancy, University of Nigeria, Enugu Campus.

EseTheresa Esenohor

Business Education Department College of Education warri, Delta State.

\section{Odiachi Laurretta}

Central Bank of Nigeria Asaba Branch

\begin{abstract}
This study investigated the level at which fraudulent accountants are prosecuted in Nigeria public sector and the extent to which fraudulent accountants are dismissed from office. The study further seeks to know if the rate of prosecution of fraudulent public servants is equivalent to the rate of fraud in Nigeria public sector. The study was carried out in four states picked from the South-South and South-East geopolitical zones. Primary data were obtained via structured questionnaire. Survey design was embraced in the research. 102 auditors and 162 accountants from the four states were sampled. Convenient Sampling Technique (CSTQ) was embraced. Descriptive statistical techniques such as, charts was embraced in analyzing the data. Cronbach Alpha Coefficient (CAC) was embraced to test for reliability of the research instrument. The Chi-Square Technique (CSTQ) and the P.value Percent Techniques (PCPTQ) was embraced in testing the vividly stated hypotheses. The results revealed accountants involved in fraud scheme are prosecuted in the Nigerian public sector. Also, fraudulent accountants working in Nigerian public sector are dismissed from duty due to fraud. This is the indication of the percentage $p$-value of 58.02587667. While $P$ value of $27.12066903888888 * * * *$ show the rate of fraudulent accountants working in Nigerian public sector not dismissed from duty due to fraud. The study recommended that accounting professional bodies and accounting standards setting body nationally and globally, for instances the Institutes of Chartered Accountant of Nigeria (ICAN), ANNA, FRCN, ACCA; ACFE among others should outline active and purposeful prosecution guideline for fraudulent accountants nationally and internationally. Implementation framework should also be followed diligently and strategically.
\end{abstract}


Keywords: Accountants, Prosecution, Fraud Schemes, Fraudulent, Nigerian Public Sector, Fraudulent Accountant, Accountants Prosecution.

\section{Introduction}

In 2002 WorldCom, a telecommunications corporation was trapped inflating assets by $\$ 11 b$. In the same accounting period, Tyco's CEO and CFO embezzled $\$ 150 \mathrm{~m}$, giving themselves loans, and overstated the company's proceeds. Furthermore, in 2009, an Indian IT services and back-office accounting firm, Satyam, boosted its revenues by $\$ 1.5 \mathrm{~b}$. Accounting fraud scheme, like these, occurred in the preceding 20 years, and burned billions of dollars (Tutino \& Merlo, 2019). Also, Sorensen and Miller (2017) in their examining the Enron and Parmalat fraud schemes that took place in the US and Italy, and their regulatory structure previous to and subsequent to the events, have noted the resemblance between EU and US legislation. Definitely, after the Enron financial fraud schemes, the US released the Sarbanes-Oxley Act (2002) provided the majority of the control and audit changes, which currently is in operation in several companies. The US and non-US companies listed in the American Stock Exchange (ASE) must conform to the SOX guidelines of 2002. As a result, a European company which had its shares listed in an ASE formerly had to obey the European Law (AL) and then afterward, it has to obey the Sarbanes- Oxley Act of 2002. Due to this extended and luxurious procedure for public companies, and following the Parmalat scandal, the EU decided to restructure its Statutory Audit (SA) to advance the audit quality and to align with the SOX previsions. Wolfe and Hermanson (2004) noted that fraud examiners should not take too lightly the fraud schemes perpetrated for the reason that the perpetrator sometimes the accountants would be smart enough to comprehend and take advantage of internal control weaknesses.

Jones (2011) highlighted 5 macro-techniques of accounting fraud schemes: inflating revenue; reducing expenses; increase assets; decrease liabilities; increase cash flow. Each of these maneuvers might be fulfilled enhancing or diminishing the sum recorded in accounts of the macro-areas of the financial report. Noticeably, there is a maximum beyond which these finetunings could be done, or else it becomes prohibited. Some instances could be the increase of worth of the goods during the closing inventory or the improvement of those assets which are considered intangible. These are only a little of the numerous techniques with which managers can fix accounting information and increase company profits, without committing any fraud.

Meanwhile, in recent time, there have been a number of efforts to trim down accounting fraud and corporate fraud by European nations and the rest of the globe. Generally, after financial fraud schemes (Enron, WorldCom and Parmalat) that shed light on the several loopholes which characterize regulatory systems, states determined that it was moment for a change. There has been a remarkable corporate regulatory restructuring that has enhanced the mechanism of in-house governance and disclosure requirements, and has strengthened public enforcement (Enriques \& Volpin, 2007). Even while accounting fraud schemes could generate principle issues in the long run and be a risk for the corporation, there could be a contradictory situation where numerous principle issues put together with other factors are able to create some fraudulent behaviours (Tutino \& Merlo, 2019).

Fraud can hardly be perpetrated in an organization without the knowledge of the accountants working in the organization. The accountants are the stewards of the organization resources 
and are expected to give details information on the financial resources on his organization. The accountants are not expected to be fraudulent. Accountants are expected to be honest, objective and truthful. However, over the years, some accountants are involved and perpetrators of fraud scheme in but the private and the public sectors. A good number of studies had been conducted on fraud in Nigeria and outside Nigeria (Benford, 1938; Altman, 1968; Beneish, Etuk 2011; 1999; Digabriele, 2009; Enofe et al., 2017; Osagioduwa, 2019; Bhasin, 2016; Hegazy, 2017; Kolar, 2013; Quirin, 2014) but no study to the best of the researchers knowledge have been carried out on the prosecution on fraudulent accountant in Nigeria and outside Nigeria. The pertinent question therefore is fraudulent accountants prosecuted accurately in Nigeria public sector? On this background, the research therefore broadly seeks to determine the level to which fraudulent accountants are prosecuted in Nigeria public sector. The specific objectives of this research are to:

1. Determine the extent to which accountant involved in fraud scheme are prosecuted in the Nigerian public sector.

2. Find out the level to which fraudulent accountants working in Nigerian public sector are dismissed from duty due to fraud.

3. Ascertain the extent to which fraudulent public officers are assisted by accountant in perpetrating fraud in the public sector in Nigeria.

\section{Concept of Fraud}

The American Institute of Certified Public Accountants (AICPA) defines fraud as a premeditated act that results in an inaccurate material declaration to the financial statements. AICPA definition considers two groupings of incorrect statements in financial statements (AICPA Auditing Standards Board, 2002). These consist of abnormalities arising from deceitful financial exposure such as misrepresentation of accounting records and forged statements resulting from embezzlement of assets as asset theft or counterfeit expenses. Also, the Association of Certified Fraud Examiner (ACFE) (2007) defined fraud as any premeditated or calculated act to dispossess another party of property or wealth by deceptive means. Furthermore, the EFCC Act (2004) sees fraud as an aggressive, unlawful and illegitimate activities committed with the intention of earning prosperity illegitimately, in a way that contravene existing legislation and these include any variety of fraud which are money laundering, misappropriation, corruption, looting, payroll fraud among others. Adetula and Amupitan (2018) cited in Evelyn and Oladipupo (2020) defined fraud as the act of purposely lying or cheating to gain an advantage or to cause somebody else to suffer a loss.

In another view, fraud is probably a covid $19^{\wedge} 5$ (19 raise to the powers of 5) virus that sneezes deceit, with hot embezzlement and regular intentional act of injustice dominant in both the private and public sectors of every country. While the Covid 19 virus could not penetrate some nations like Jamaica, Covid $19^{\wedge} 5$ viruses has no limitation. The cure for this Covid $19^{\wedge} 5$ viruses is yet to be discovered by several developed and developing countries of the world. The death rate from Covid $19^{\wedge} 5$ virus cannot be estimated but Covid 19 death rate according to worldometer as at 23 May 23, 2020 is 340,699 only. It is interesting the Covid $19^{\wedge} 5$ viruses had significantly influenced the spread, practice, politics schemes and effect of the Covid 19 
virus in Nigeria particularly. An instance is the lack of usable and equipped hospitals which Covid $19^{\wedge} 5$ viruses caused when Covid 19 virus arrived the shores of Nigeria.

\section{Fraud Vs Creative Accounting}

Amat and Gowthorpe (2004) noted that creative accounting (CA) is a practice identified for the earliest point in studies by the lan Griffith in 1986, and then it spreads itself around the rest of the globe. Although there is not a particular description of the phrase, it has diverse meanings depending on the nation where they are defined. In the United State, CA is not only an officially authorized operation intended at adjusting accounting figures, but has a wider connotation, incorporating in itself also fraud. Nevertheless, in literature, it is general to find this practice under other nomenclatures, such as "earning management" or "income smoothing". Instead, in European literature, it is known with the unique name of "CA" (Amat and Gowthorpe, 2004). In a different way, in the UK, CA is considered only as a practice within the regulatory structure and absolutely legitimate. The opening definition of the concept was given by lan Griffiths (1986) in his paper "Creative Accounting". The author began claiming that: "Every business in the nation is fiddling its earnings. Every set of published financial statements is based on records which have been quietly cooked or completely roasted. The records which are fed two times a year to the investing community have all been altered in order to defend the guilty. It is the leading con trick since the Trojan horse. In reality this fraud is all in perfectly good taste. It is entirely justifiable. It is CA. Michael John Jones (2011) recognized that $C A$ is based on the elasticity of the regulatory structure. It tries to repair accounting data in order to benefit those who prepare the financial statements for the stakeholders, who employ the data to make profitable decisions.

Consequently, flexibility is an indispensable quality of the structure so that companies possibly will "cook the books". Regardless of the endeavor of regulators, it proves very tough to eradicate CA due to the intention of a financial statement, that is to give a "true and fair view", and it requires a definite degree of versatility. In addition, approximately all the European regulatory systems have this intention. Both CA and accounting fraud are practices that necessitate the engagement of deceit, and then it is frequent that these two terms are exchangeable. However, among them, there is a significant difference represented by the legitimate area where creative accounting operates (Tutino \& Merlo, 2019). The main actors in CA are not only managers or executives but also mercantile bankers, with the idea of presenting financial records in a more constructive way for their interests. On the other hand, regulators and company auditors try to alleviate this practice with laws, and other best practices that promise a true and fair view. The primary subjects to have an interest in enhancing a company's profits are managers. They employ CA to fix accounting figures, by increasing earnings or declining expenses. One of the major risks which companies run is that they commence modifying a number of elements of the financial statement, and it ends with overcoming the boundary beyond which the CA becomes fraud (Jones, 2011). The motivations behind these actions are repeatedly connected with the manager's wages, which could be connected with corporate performance or with dividend if managers are also shareholders. Further, Shah et al (2011) recognized a number of the major interests of managers, such as the accomplishment of internal goals and external opportunity, the attainment of tax incentives and "window dressing" operations before an IPO or a loan. 
INTERNATIONAL JOURNAL OF ACADEMIC RESEARCH IN BUSINESS AND SOCIAL SCIENCES Vol. 12, No. 1, 2022, E-ISSN: 2222-6990 ๑ 2022 HRMARS

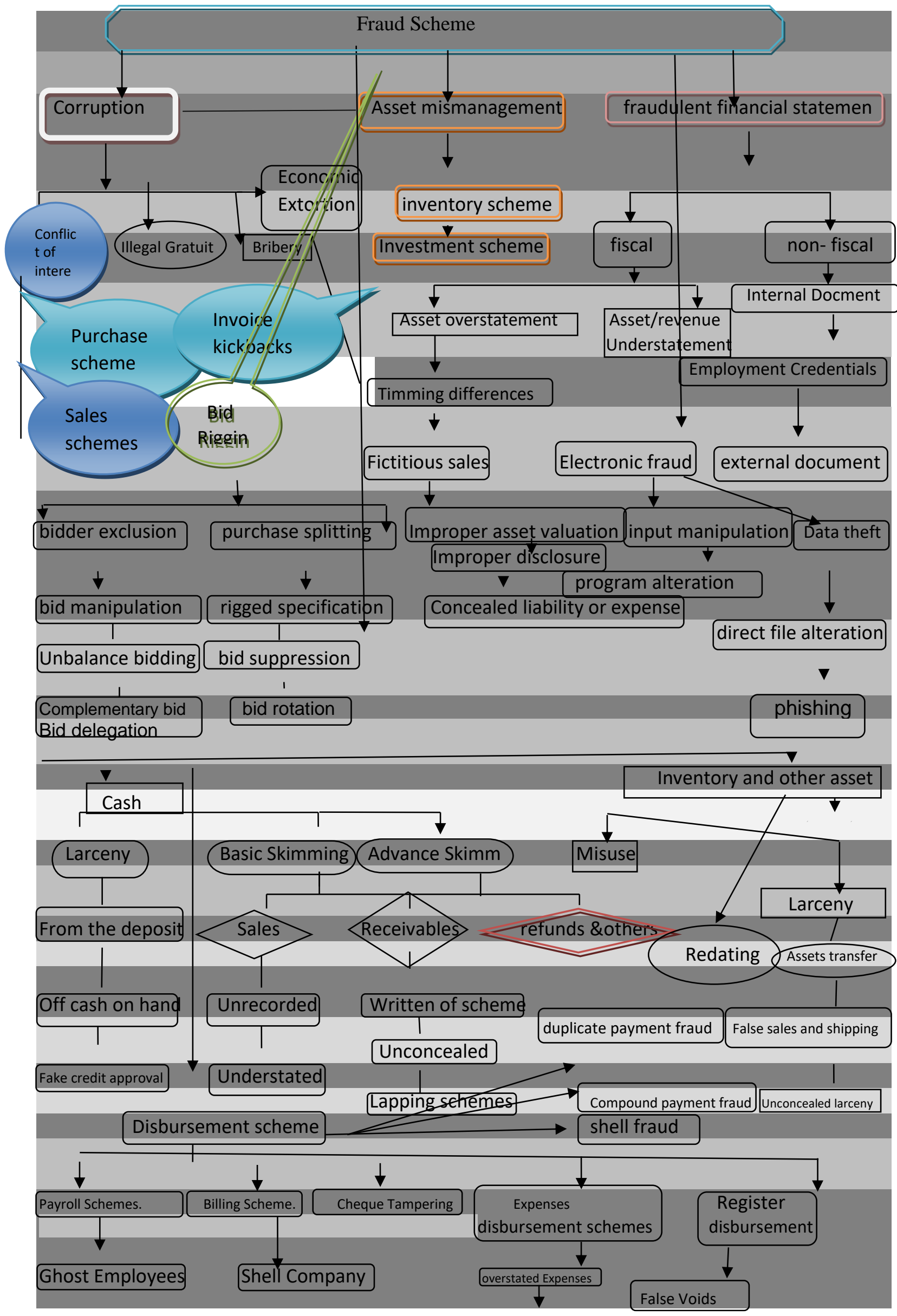




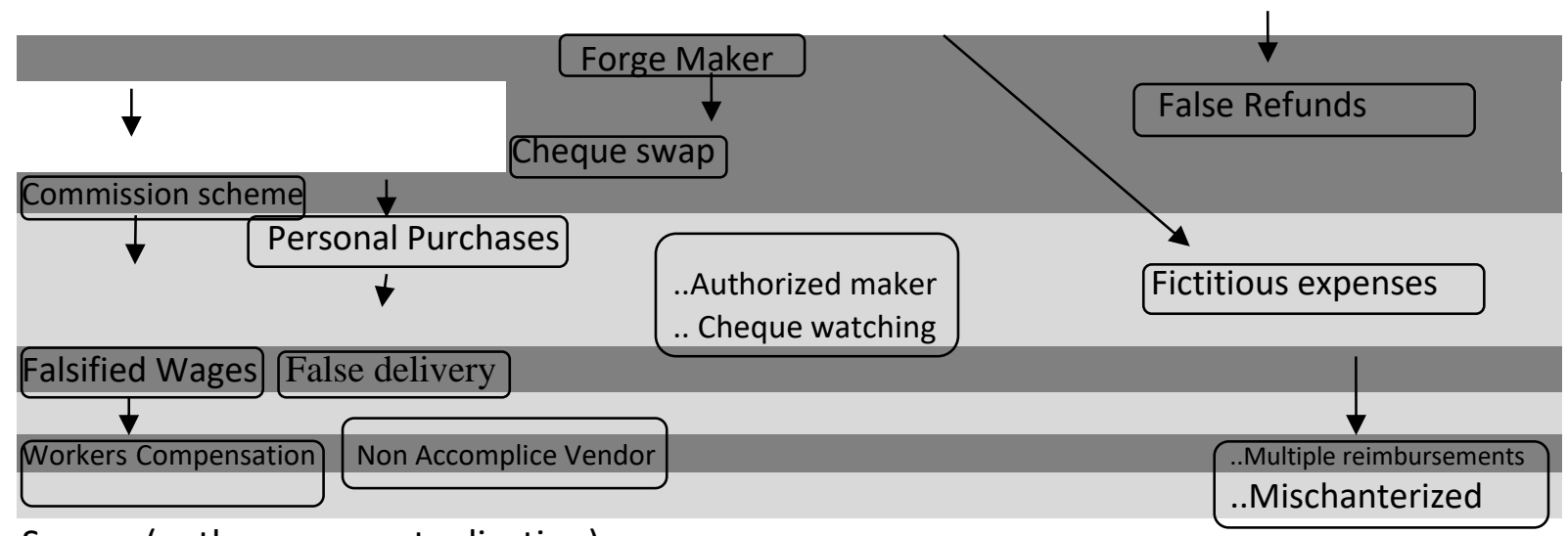

Source (authors conceptualization)

Basic Skimming: in basic cash or sale skimming, sales representatives or agents makes sales. The transaction is not recorded. Embezzled the sales revenues in his individual or collective scheme and refuse to issue receipt to the customers. A simple solution is to employ customer audit.

Advance Skimming: advance skimming can be in cash during sales transaction. Here sales representatives or agents make sales and deliberately refuse to enter the transactions in the accounting books and account. However, he advance in issuing the customers a falsified or forged receipt and comprehensively pocket the money. One of the ways out is to employ prenumbering of receipt.

Larceny: Skimming is the word used when the money receipts are taken after being recorded in the accounting records; as a result, the sale is reflected in the company's books and records. While in larceny, if the debit entry to the sales entry is cash, cash will not balance. More often, the debit entry will be to receivables so that cash remains in balance.

Cheque swap: the scheme here is that cheques are swap for cash. The fraudulent employer or cashier replaces cash collected with fake cheques.

Cheque tampering: in this scheme, the cheque is altered or distorted and someone else is entitled to receive the payment. The distortion and altering can be in the written figure (amount) or name contained in the cheque. A biro pencil is employed in entering the amount or name and erase later. The perpetrator takes substantial control of a Cheque and makes it payable to either himself, "shell corporation" he controls, to an "accomplice", or to cash. The design can include getting a blank Cheque stock or taking Cheque after being made payable to other parties and changing them so that they are payable to the advantage of the fraudster.

Cheque watching: here, the fraudulent employee apply relevant chemical on the targeted cheque to eliminate and erase the written amount on the cheque and write a falsified figure on the cheque.

Receivable (Lapping Scheme): Account receivable fraud entails lapping of the account receivable. The cashier will track an incoming monetary payment and will deliberately keep the financial transaction off record. He will make use of the latest income to substitute for his fraudulent actions or scheme. While lapping, a prior unrecorded sale is lapped with new or 
latest sales. For instance, the perpetrator embezzle the payment intended for customer MNO's account. When a monetary payment is acknowledged from customer XYZ, the thief credits it to MNO's account. And when customer ABC pays, that money is credited to XYZ. This exposes the legitimate receivable to non collection because it is improbable that the rightful customer will pay double for the same purchase.

Fraudulent (fake) credit approval: this entails granting or approving credit without compliance and conformity with duly establish and legal procedures and processes in the organization in line with the internal control. Entails improper credit to customers, and improper write-up to customer's account. Example could be writing bad or doubtful debts were it does not exist.

Financial: These are fraudulent scheme and design in relation to monetary or fiscal matters in the public sector or private organizations.

non-Financial: These are fraudulent scheme and design in relation to assets other than direct financial in the public sector or private organizations.

Direct file alteration: generally, organization operates computerized operating system in the current century. Personnel of the organization more often than not own a log-in password to the company or organization files and essential database. Some fraudulent personnel use tailored tools to distort the data in figure in the general organization database. Audit trail is not established. Highly skilled electronic fraudsters are able to log on to the general ledger without being seen or recognized. File encryption of accounting file can aid in resolve the dilemma.

Program alteration: here, software programmers include an authorized charges or modification in the accounting software during. For example, a programmer places intentionally a patch in a payroll processing code system making it feasible for some fund to go to a separate account or another person.

Phishing: Phishing involves fraudsters who send messages to attract personal detail (credit card numbers, bank account information, Social Security Number SSN, passwords, BVN, or other sensitive information) from unsuspecting victims.

Assets mismanagement Scheme ASMS: This type of fraud involves the theft of cash or inventory, property, plant and equipment PPE, revenues, payroll fraud, and stationery. ASM is the most frequent category of fraud. Among the other brands of assets frequently misstated are investments, non-current asset CNA, leased assets, research and development costs, advertising costs, software development costs, and interest costs (Association of Certified Fraud Examiners, 2002).

Fictitious Sales FSS: A general method is to generate fictitious orders for either existing or pretended customers. Recording a FSS in an organization's accounts and records is as uncomplicated as recording a credit to the general ledger. Counterfeit supporting documentation is created to hold up the non-existing products or services never rendered. Though, the fictitious account receivable that must be fashioned in this design will never be collected. Eventually, this uncollected FSS will age; that is, it will grow old and older and become thirty (30) days, then sixty (60) days, then ninety (90) days, and eventually, one 
hundred and twenty (120) days and More-past due. Long-past-due receivables usually catch the attention of management; therefore, they need to be concealed.

Redating: here the company and firm receivables are redated to a more current and present date. This keeps the sales amount from being captured in the bad debt reserve. However, the receivable is still at risk of being chosen by the auditors for confirmation.

Inventory Scheme INSE: when inventories are sold, the figures are moved to cost of goods sold and included in the income statement as a direct reduction of sales revenue for the period. An excess valuation of closing inventory understates cost of goods sold and in turn overstates net income. INSE generally fall into three groupings: one; artificial price increase of the quantity of inventory on hand. Two; inflation of the value of inventory by postponing write-downs for obsolescence, manipulating the unit of measurement to blow up the value and underreporting reserves for outdated inventory. Thirdly; fraudulent or unacceptable inventory capitalization method (COSO, 1987).

Investment Schemes INSC: Fraudulent INSC offer another technique for a corporation to overstate current and none-current assets by creating fictitious investments or intentionally overvaluing existing ones. Companies can maneuver and intentionally influence their financial statements and accounts by inflating the value of investments, misclassifying them or weakness in record unrealized decline in market price for those investments. Companies can maneuver financial statements by purposely misclassifying securities or transferring securities to a category that would prompt the recognition of gain or, on the other hand, postpone recognition of a loss.

Disbursement Schemes DSS: A fraudulent DSS is a payment of an organization's funds with the intention that is not discharged to advantage of the organization. That is, the payment satisfies no requirement and serves no need of the organization. In contrast to schemes that steal cash at point of entry, fraudulent DSS involve theft of funds already entered and recorded into the books of accounts and records.

Expenses Disbursement Scheme EDS: EDS may seem like miniature change when compared with billions of naira in deceitful overstated inventory. Our experience is that if a member of staff is submitting forged or falsified expenses, that scheme may be a probable red flag indicating other aspects that may be subject to abuse and fraud. Similar process applies for voyage and expense reports as it does for purchase cards. Classically, purchase cards are employed for smaller-dollar items; nevertheless, fraud may transpire when no one assesses the details of statements from purchasers.

Payroll Scheme POS: POS represent the payment of remunerations or other forms of payment in surplus of that earned by the member of staff. This is most frequently accomplished through the use of ghoul, apparition and phantom employees and the falsification of time cards. Analytical review of and reasonableness tests related to payroll expense could reveal irregularities. Data mining, an effective detection technique for payroll schemes, can include data interrogation queries to identify. 
Kickback KK: KK are over and over again the most complex of allegations to prove and provide evidence. The most convincing proof is admittance and acknowledgement by the recipient or the vendor. On the other hand, both parties are benefiting from the corrupt action and have no incentive to tell the fact. Additionally, kickbacks are not habitually paid in front of witnesses; there is little, if any, documentation to establish that kickbacks have occurred; and they are frequently paid in cash. For these cause, they're complicated to trace. Kickbacks may greatly increase costs over a period of time, and those costs are often not at all apparent in the records.

Bid Rigging BRG: BRG is a fraud scheme in procurement auctions in non-competitive bids and can be performed by corrupt staff, by organizations in an orchestrated action of collusion, or between officials and organizations. This form of collusion is illegitimate in several nation nations of the word. It is a kind of price setting and market allocation, often practice where contracts are determined by a call for bids, for instance in the case of government construction contracts. The typical objective of bid BRG is to aid the winning party to win the contract at uncompetitive price (Wikipedia, nd).

Bid Exclusion BE: here a contract or project advertisement is made to selected bidders or bidding markets, thereby reducing publicity of bids procurement.

Duplicate Payment Fraud (DPF): DPF type of fraud is committed by making payment for a financial transaction that does not really existed. For instance is and employee issuing two more identical cheques to pay the same debt or liability.

Compound Payee Fraud (CPF): CPF involve two or more payments to different payees for the same transaction or service rendered. One of the payments will be to a rightful payee, the other will be fraudulent and the fundamental documentation is switched to maintain the counterfeit transaction. Commonly this nature of fraud is more complex to discover in compare of previous one.

Shell Fraud (SF): SF is like the object beneath the shells, the article that was purchased and paid for does not exist and on no account existed. In this category of fraud perpetrator conceives of a imaginary purchase and prepares official procedure and accounting entries, forging whatever signatures are considered necessary.

Purchase Splitting: entails reducing the least bidding price. This reduces competitive bidding and enables less oversight at the project level as bid amount drop and kickbacks can be allotted.

Bid Manipulation: it occurs after the receipt of bids. The method for this would include either changing bid parameters, evaluation processes, or other activity to effectively pick the bidders choice.

Rigged Specification: this allows other bidders' inclusion by staff by either tailoring request to individual's bidders or creating a vague criterion to reasonably choose a preferred bidder.

Unbalance bidding: this entails high bid prices for commencing stages of development and low prices for later stages. 
Bid suppression: occurs when some of the conspirators agree not to submit bids allowing another conspirator to win the contract.

Complementary Bidding: also called cover bidding or courtesy bidding, occurs when some of the bidders agree to submit bids that are intended to be unsuccessful, so that another conspirators can get the contract.

Bid Rotation BRN: this occurs when bidders take turns being the designated successful bidders. For instance, all conspirators are designated to be the triumphant bidder on a definite contract, with conspirators nominated to win other contract.

Bid Delegation BDN: can be a factor fostering the presence of bid rigging. For instance, it is the case of marketing agencies that bid for the same ad space on behalf of different and competing agents

False Delivery FD: here the buyers order for a specific quality of a product. On delivery, the company places the high quality ordered for on top of the product delivered and load beneath with inferior quality product. The buyer only inspects the high quality product on the delivery and assumed that the others are same.

Corruption: World Bank cited in Osagioduwa (2019) sees corruption as the mishandling of public office for private benefit. Similarly, corruption is the exploitation of public power and office for private or personal gains (Enweremadu \& Okafor, 2009; Vian, Brinkerhoff, Feeley, Salomon \& Nguyen, 2012)

To conceal involvedness and to mislead investors, declining and failing firms have resorted to the succeeding misleading reporting practices. (1) advance recognizing of earnings, (2) inappropriately treatment of operating leases as sales, (3) inflated inventory by improper application of the LIFO inventory technique, (4) included fabricated figures in inventories, (5) failed to acknowledge losses via write-offs and allowances, (6) inappropriately capitalized or postponed costs and expenses, (7) including extraordinary gains in operating earnings, (8) overestimated marketable securities, (9) created "sham" year-end transactions to improve reported earnings, and (10) charged their accounting practices to augment earnings without unveiling the changes (John \& Perry, 1984).

Corruption: World Bank cited in Osagioduwa (2019) sees corruption as the mishandling of public office for private benefit. Similarly, corruption is the exploitation of public power and office for private or personal gains (Enweremadu \& Okafor, 2009; Vian et al., 2012)

\section{Prosecution}

The English dictionary defined prosecution as the process of prosecuting a scheme or endeavor. It was also defined by the English dictionary as the institution of legal proceedings (principally criminal) against a person. There is absolutely a dramatic boost in the number of claims against Certified Public Accountants (CPAs) and in the amounts required by claimants as a result of the increasing scope of accountants' liability and RICO (Racketeer-Influenced and Corrupt Organizations Act). RICO, initially employed by persons victimized by a blueprint of racketeering action to file a suit for treble damages and attorney fees has been employed 
increasingly in marketable proceedings growing out of deceitful securities offerings, commercial failures, and investment disappointment. A circumstances in which co-defendant auditors had desecrated the central mail and securities fraud acts by unacceptably auditing and issuing audit opinions on their client's financial reports on two or more particular occasions, and by engaging in the operations of their organizations the amount received for those audits, by reason of which petitioners were injured in their trade or asset, is claimed to claim a infringement of constitutional provisions of the RICO Act (James, 1982). Sincere efforts were made in 1987 to restructure the social provisions of RICO. Senate bill initiated by Senator Howard Metzenbaum carry on to permit petitioners to seek numerous damages in cases or else punished under the securities regulations if the petitioners are minute investors. An explanation of miniature investor will comprise more than fifty percent of the more than forty five million investors in securities in the US. This spells bad reports for the accounting profession. Eyewitness the subsequent statement made by Lee, the AICPA's choice for testifying to the require reforming RICO.

According to Amoz and Hilkiah (1046-616 BC) God prosecuted a fraudulent young man in the holy writes. They noted that Gehazi collected leprous resources in the name of his master. But he went in, and stood before his master claiming innocence. And Elisha said unto him, whence are you coming from? And he said, your servant went no whither. And he said unto him, went not mine heart with thee, when the man turned again from his chariot to meet you? Is it a time to collect money, and to collect garments, and olive yards, and vineyards, and sheep, and oxen, and menservants, and maidservants? The leprosy therefore of Naaman shall come upon you and unto your children for ever. And he went out from his presence a leper as white as snow.

\section{Accountants Prosecution in the Nations}

Furthermore, of maximum concern to the accounting profession is the verity that RICO continues to be employed to evade the standards of the securities regulations and to raise the stakes in common litigation arising from securities transactions (AICPA, 1988). Fraudulent instances that involve accounting professionals will keep on to be prosecuted with RICO liability in mind. In these fraudulent instances accountants have established themselves named as co-defendants. The justification behind the courts proneness to hold accountants legally responsible for losses connected with business collapse results from the principle that auditors (a) can best avoid the losses connected with business failures and (b) can share their liability via insurance (Richard \& Douglas, 1987). What auditors face is a hazardous hazard that is trial by board of adjudicators, particularly with the risk of RICO-treble damage judgments.

The federal, state and local governments might vary in choosing which cases to prosecute, the principle that guides every of them is that they are duty bound to shield the public from damage. The more damage they perceive, the more probable they are to pursue prosecution. A consequential principle is that prosecutors at all points of government are funds constrained, and consequently, you may find out that the recommendation of a fraud scheme matter has to linger in line behind more urgent priorities (Albert et al., 2006). Fraud scheme can be overwhelming on an individual level when a corporation collapses and workers lose their savings, pensions, and jobs. Regardless of the important personal impact, prosecutors however have many justifiable demands on their resources; focus the concentration on a 
prosecutor on a fraud scheme case may be difficult. A number of forensic accounting groups can use their extensive experience to present the case in a manner that best deals with the prosecutor's concerns about funds limitations and complication (Albert et al., 2006). Despite the jurisdiction, the procedure may take as much as a number of years. Bear in mind that the authorities are not essentially fascinated in determining the complete loss. They are not personal investigators. They are looking only for adequate proof to satisfy the needs of a successful scandalous prosecution. For instance, say a manager or accountant has been stealing for a number of years by earnings of fraudulent invoices scheme paid to forged vendors. Supplementary, the prosecutor identifies N5, 500,000 in larceny over a one-year period. The corporation might have some unanswered questions: How long did this fraud scheme be going on? How much was embezzled in totality? Are there coconspirators? Were there other fraud schemes? These questions are appropriate to the company, but not essentially to the prosecution. The board may need to carry out an internal investigation to respond to these questions (Albert et al., 2006).

Furthermore, the forensic accounting investigator might probably be a vital component of the prosecution squad by helping assess proof of financial fraud schemes and by advising the client and the prosecutor. The forensic accounting investigator (FAP) can recognize weaknesses in the evidence and possibly recommend substitute investigative procedures to lessen any risks that have been known. For instance, if the CFO has set in proposition on accounting fraud scheme, the FAPs can examine financial statements and transactions to find out what really occurred. Many prosecutors do not have the in-house expertise to perform these steps (Albert et al., 2006). A FAPs expertise in get-together and interpreting financial evidence enable the prosecutor to build up the case and prepare to disprove defenses. Once a FAP is involved, it is imperative for that person or team to carry out a very comprehensive investigation. For instance, if the weight of the defenses offered by the suspect during admission searching interviews is not tested, that may leave a limitation. At a trial, there is a significant dissimilarity between testifying FAP. The testifying FAP is helping as a expert witness at a criminal trial. The FAP's task is to communicate the facts that that investigator has determined to be relevant to the matter at hand. While actual situations will differ depending on the circumstances, as a broad matter it means the forensic accountant does not offer an opinion about Fraud as in, "Yes, in my view a fraud has been committed, and the defendant did it" but, rather, presents evidence connected to all of the elements of fraud in such a way that the trier of fact in the form of judge may reach a conclusion based on the facts the forensic accountant has discovered(Albert et al., 2006).

Virgina (2019) affirmed that Carilliona construction firm bowed under the weight of a $£ 1.5 \mathrm{~b}$ debt. Carilliona was established in 1999 subsequent to the demerger from Tarmac, it grew to become the UK's second leading construction company, employing approximately 40,000. Concerns about its increasing debt first emerged in 2015 and in 2017 it fell out of the FTSE 250 following a harmful trading announcement. That year it issued three profit cautions in 5 months and wrote down above $f 1 \mathrm{~b}$ in value of contracts. In the early hours of 2018 it was announced that the UK Financial Conduct Authority (UFCA) was to probe its announcements from 2016 December concerning its finances; after days of high-level legislative talks and efforts to locate a liberator, the company was declared bankrupt, with a $£ 900 \mathrm{~m}$ obligation pile and $£ 600 \mathrm{~m}$ pension arrears. Furthermore, In May 2018 a parliamentary committee noted clearly that its collapse was as a result of "recklessness, hubris and greed." Accountants KPMG, which earned $£ 1.5 \mathrm{~m}$ a year from the Carillion account, came in for very heavy 
criticism, accused of rubberstamping records that distorted the actuality of the business as well as incurring a conflict of interest owing to its work advising the pension scheme. There were calls to break up the Big Four and make auditors accountable to Parliament.

In 1926, café chain Patisserie Valerie was founded and acquired in 2006 by Luke. Rapid growth followed, with the chain growing from 8 shops in the year of possession to 192 by 2017. In 2018 trading in the shares of Patisserie Holdings, the parent company, was suspended due to the discovery of potentially fraudulent accounting irregularities (Virgina, 2019). Shortly, the company announced that there was a material deficit linking the reported monetary status and the present fiscal status of the business, after which a man was detained on suspicion of fraud by forged representation. In January 2018 the company announced it had shrunken into administration following unsuccessful rescue talks with banks. In February, administrators KPMG agreed an executive buyout funded by Causeway Capital Partners (CCP). On October 2018 for the Auditor Grant Thornton came in for stern criticism for signing off the very last year accounts in November 2017 with net cash given to be $\mathbf{2 1 . 5 m}$. Chief executive David Dunckley was called by select committee where he averred that it was not the auditors' responsibility to look for fraud; MPs disagreed and the occurrence looks sure to strengthen the case for the CMA proposals (Virgina, 2019).

Ray Kelvin opened his foremost Ted Baker in Glasgow in 1988 and the company grown to become a FTSE 250-listed luxury clothing range with 490 stores and recognitions globally. In August 2018 KPMG was fined $f 2.1 \mathrm{~m}$ by the Financial Reporting Council (FRC) subsequent to the admittance of fraud in the financial statements in 2013 and 2014, while KPMG partner Michael Francis was in person reprimanded by the controller and fined a further $£ 46,800$. The fraud arose from KPMG providing professional witness services to Ted Baker in London proceedings. On August 2018 As well as heralding an annus horribilis for KPMG, which was singled out for the "unacceptable" turn down in the quality of its auditing (Virgina, 2019).

According to Virgina (2019), BHS, the department store chain created in 1928, was acquired by Philip Green in 2000 and formed part of his Arcadia Group. In March 2015 it was put up for sale for a nominal $f 1$ to Retail Acquisitions Ltd led by the successive bankrupt Dominic Chappell; barely a year later it entered management, putting 11,000 jobs at jeopardy. Duff \& Phelps were selected managers of the business, which had $£ 1.3 \mathrm{~b}$ in debts plus $f 571 \mathrm{mn}$ pension debt. Qatari Al Mana Group acquired the company's global franchise stores. The insolvent division of the company went into bankruptcy on December 2016. PwC, which gave the business an unqualified report for the year up to August 2014, came in for a stern scolding and record $f 6.5 \mathrm{mn}$ fine from the FRC in June 2018, condensed from $f 10 \mathrm{~m}$ after it settled to cooperate. Steve Denison, the accountant who audited the accounts, was fined $£ 325,000$, down from $£ 500,000$ after agreeing to collaborate and given a 15 -years proscription.

Ajay and Rajesh Gupta moved to South Africa from Uttar Pradesh in 1993 and established the Sahara Computers, with the group growing into mining, energy, air travel, technology and media. The relatives became very close to Jacob Zuma, leading to accusations of "state capture" and extensive fraud, but the business began to collapse in 2018, with some Gupta business filing for administration. On February 2018 Jacob Zuma left and immediately the Gupta brothers moved out supposed to have fled the state to Dubai. Shortly Ajay Gupta was affirmed an escapee from justice by the South African government after failing to hand 
himself over. The crumple took place in February 2018. KPMG had been engaged and came in for very intense criticism for audit work done for the Guptas, with whom it had audited for 15 continuous years until stepping down in the year 2016. Ex-KPMG auditor Jacques Wessels was afterward charged with inappropriate conduct and tax evasion. This scandal disclosed the question of correlation between company and auditor potentially being too close (Virgina, 2019).

General Electric GE was established in the year 1892 through a amalgamation with one of the companies fashioned to aid Thomas Edison's lighting experiments, GE is an American colossus. However, at the commencement of 2018 it was declared that the SEC was investigating its "aggressive and fraudulent accounting" practices, a query that widened all through the year when in October 2018 its $\$ 22$ b non-cash charge connected to acquisitions came under examination, with the Department of Justice also initiating an investigation. GE's market value drop by more than $\$ 200$ b over 2 years. KPMG audited GE's for over a century. The association between the 2 companies was expressed as too homely emblematic of the apprehensions highlighted in the CMA statement about appointing accountants with whom a company has "chemistry" (Virgina, 2019).

Association of Certified Fraud Examiner (2017) noted that a seemingly continuous stream of fraud accounts hits the headlines. Shortly, Ivy League educated financier defrauded his client of amount above $\$ 38 \mathrm{~m}$. A European football star is spending his day in court. If anyone has learned anything from taking history lessons in school it's that understanding the past helps to keep away from repeating it. By exploring 10 prominent fraud cases of the 21st century, fraud examiners can recognize the methods the foremost players employed to conduct their fraud schemes, and investigate the outcome and impacts of different frauds.

In the year 2002, the WorldCom scandal became one of the major accounting frauds in record when the company revealed its unlawful activity and was afterward forced to file bankruptcy and write off $\$ 50 \mathrm{~b}$ in losses. The scandal started when WorldCom CEO Bernie engaged a business strategy of achieving expansion through acquisitions. Determined to show increased income regardless of a slow-down in amalgamations and acquisitions, Ebbers manipulated the records to please Wall Street's expectations. The design was detected when a principal expenditures audit revealed doubtful journal entries (Association of Certified Fraud Examiner, 2017). WorldCom's internal audit team revealed unacceptable accounting in expenses over 5 quarters. The WorldCom accounting scandal was a condition in which corporate governance was unsuccessful and the board of directors was trapped unaware. WorldCom's accounting structure was flawed and Ebbers' close association with external accounting firm Arthur Andersen showed a conflict of interest in which the auditors were incapable to work out professional skepticism when performing their audits (Association of Certified Fraud Examiner, 2017).

Top-profile sports are huge business in several nations. Regrettably for the International Federation of Association Football, suspected corruption and money laundering means its large business operated with small or no supervision. The FIFA fraud schemes involved the agreement among FIFA's executives, sports marketing directors and executives of continental soccer bodies. The fraud scandal erupted in 2015 when Swiss government raided a notable hotel in Zurich were several FIFA executives were detained (Association of Certified Fraud 
Examiner, 2017). Furthermore, the U.S. Department of Justice (DOJ) has cited above forty (40) defendants in the FIFA fraud schemes. A number of charges entail bids for World Cups and for promotion and broadcast deals that summed to almost $\$ 150 \mathrm{~m}$. Future World Cups are currently in question. The fraud scandal caused the bidding procedure for the 2026 World Cup to be suspended. Projected alterations have been made, but only time will tell in an organization that has previously dealt with inducement and corruption (Association of Certified Fraud Examiner, 2017).

In the year 2012, British pharmaceutical company GlaxoSmithKline (GSK) was at the hub of the biggest health care fraud scheme in record when the company decided to compensate $\$ 3 b$ as fines to U.S. regulators. According to the U.S. Justice Department (JD), GSK illegally promoted certain prescription drugs, failed to report safety data, paid kickbacks to health care professionals and engaged in fraudulent pricing practices. The settlement arose from a number of GSK policies and practices that basically involved the sponsorship of prescription drugs, like Paxil and Wellbutrin, for off-label use (Association of Certified Fraud Examiner, 2017). While doctors may prescribe drugs for off-label use, it's illegitimate for pharmaceutical firms to endorse or market off-label uses. The U.S. government also claimed that GSK paid unlawful kickbacks to health care professionals to encourage them to recommend definite drugs. While much of GSK's wrongdoing was exceptional to the pharmaceutical and health care industries, the case contains extensive lessons. A company's traditions should stress conformity and ethical conduct (Association of Certified Fraud Examiner, 2017).

The Olympus fiscal scandal exploded in 2011 when then leader and CEO Michael Woodford came onward with information revealing fraudulent accounting practices in the company. Woodford had only served as CEO for 14 days when he exposed the financial malfeasance. The fraud is one of the momentous corporate corruption scandals in the record of Japan. In 2000, standards in Japan distorted extensively after the failure of Yamaguchi Securities in 1997 (Association of Certified Fraud Examiner, 2017). The novel accounting standards required losses on definite assets to be noted at the conclusion of each accounting period. Rather than conform to the standards and reveal escalating losses, Olympus constructed a problematical structure of hiding its bad assets. The company began advertising bad assets for inflated prices to recently formed entities under its control without recognizing losses from the sales. The Olympus fraud demonstrates that tendency at the top matters. Woodford wrote letters to the board about his concerns and was consequently fired. This exemplified the company's unprincipled culture (Association of Certified Fraud Examiner, 2017).

\section{Accountants Prosecution in Nigeria}

Soni (2020) noted that an accountant working with a church in Adamawa State was prosecuted and sentenced to eighteen (18) years imprisonment for involvement in a fraud scheme an amount totaling N15.5 million belonging to the religious organization. The accountant Ibrahim Aku was prosecuted and sentenced by Justice Nathan Musa of the Adamawa State High Court subsequent to being arraigned by the Economic and Financial Crimes Commission (EFCC) on the foundation of a petition filled by the General Officer of Ekilisiyar Yen Uwa Nigeria, EYN, on falsification and obtaining funds by bogus pretence. The accountant was investigated and prosecuted subsequent to a petition by the church through Rev Daniel Mbaya and Secretary-General of the religious organization claiming that the accountant defrauded the church of N15.5m between 2016 and 2018 respectively. The EFCC 
told the court that its investigations had established that the money frauded by the accountant was generated by the religious organization members through offerings, contributions and tithes. The convict was entrusted by the religious organization to deposit the religious organization's income into its accounts but he ended up diverting same and forged bank tellers to balance the financial books. The agency said that the accountant was assisted in the fraud scheme by his friend, to whom he gave N500,000. His accomplice and collaborated assisted him in forging the stamps of the banks, which were also employed to perpetuate the fraud. He was prosecuted using the Advance Fee Fraud and other Fraud Related Offences Act, 2006 (AFFFROA). He pleaded responsible to the charges. The account and had since been sentenced to 18 years imprisonment. Three years in each of the courts to run concurrently.

Furthermore in Nigerian fraud scheme, Akinloye (2019) highlighted an accountant in the UK, Sam Kayode, who was prosecuted and sentenced to 9 years in prison for defrauding f4.1million. The accountant was sentenced by Woolwich Crown Court in South London for embezzling Haberdashers' Aske's state schools in the United Kingdom. The accountant, who earned $£ 57,000$ in every twelve months, was convicted after being established guilty of $£ 150,000$ and $£ 3.95 m$ theft and fraud respectively. Of the $£ 4.1 \mathrm{~m}$, just $£ 800,000$ was retrieved from him. Described as fraudulent and greedy, the court heard how the accountant lavish the loot on 4 women his wife, a second 'wife' in Nigeria, and two other women in the UK. British prosecutor, James Thacker, noted that the accountant also acquired luxury cars. The accountant was alleged to be secretive, locking himself in his office to work late hours. The accountant tried to blame the fraud on his late wife and a junior associate, saying they conspired to tarnish his figure by transferring the funds to his account in retribution for his adultery. The accountant fraud scheme was exposed when a school cleaner stumbled on some of his documents.

Also, vanguard (2019) asserted that the Economic and Financial Crimes Commission (EFCC) has arrested Director-General (DG) of Sokoto Marshal Agency (SMA), Abdullahi and the accountant of the agency, over an alleged fraud scheme, money laundering and diversion of staffs' remunerations to the tune of N10 million. They were arrested in Sokoto by the EFCC. The DG and accountant's arrest followed a prosecution and a petition mutually signed and sent to the EFCC by thirty-nine (39) members of the agency, alleging that their remunerations for 3 months were being suspended without any explanation. The petitioners additionally alleged that the DG and the accountant refused to pay their remunerations and diverted the money to private use.

In addition, Wahab (2019) asserted that the EFCC arrested Covenant University accountant for supposedly diverting only N180million belonging to the school. The accountant was prosecuted over an alleged case of embezzling. The diversion of the funds was said to have taken a good number of years before the university discovered his alleged fraud. The Chancellor of the university described the lifestyle of the accountant as riotous and unruly. The accountant has a house in the school where he lives with his spouse, but according to reports, he purportedly bought a mansion in Lekki, Lagos and some flashy cars with part of the stolen wealth.

EFCC (2019) had sent the case file of the past Accountant-General of the Federation (AGF), Jonah Otunla to the Chief Judge for reassignment. The development followed the exodus of the trial judge to the Asaba Division of the Federal High Court, and the repeated nonattendance of the AGF to appear before the Court to take his plea. AGF should had since be arraigned along with Adelakun and 7 companies for an alleged N2b fraud scheme, before 
Justice Dimgba on December 7, 2017 on a 5-count charge, but his nonappearance caused the trial to be adjourned. His nonappearance caused several adjournments, until the transfer of the judge. One of the counts reads: "That you, Jonah Ogunniyi Otunla, being the former Accountant General of the Federation and a Director and signatory to the ECOBANK account of Wehsac Farm Ltd, Otunba Ade Adelakun, being the Managing Director/Chief Executive Officer and a signatory to the accounts of Gold Reef Industries Nigeria Limited Fidelity Bank, Lambster Nigeria Limited-Zenith Bank, G.C Electronics Ltd - GTB and Sinmilak Nigeria LimitedFidelity Account, Col Bello Fadile (now at large) being the former Director, Special Duties in the Office of the National Security Adviser (ONSA) and also a Director and signatory to the accounts of Helpline Organisation- Diamond Bank and Justice and Peace Consultants- GTB, sometime between June and August, 2013 in Abuja within the authority of this Honorable Court, directly converted the sum of N2b, transferred to the accounts of Goldreef Industries Limited-Fidelity Bank N550m, Lambster Nigeria Limited- Zenith Bank N650m, G.C Electronics Limited - GTB N450m and Sinmilak Nigeria Limited- Fidelity Account N350m from the account of the Office of the National Security Adviser with the Central Bank of Nigeria, purporting to be for the supply of security equipment when you reasonably ought to have known that the said fund formed part of the proceeds of an unlawful activity of Dasuki the then National Security Adviser (NAS) and thereby committed an offence contrary to Section 15 (2)(b) of the Money Laundering (Prohibition) Act, 2011 as amended in 2012 and punishable under Section 15 (3) and (4) of the same Act." Prosecuting counsel, Sylvanus Tahir, informed the court that "it will be better to transfer the matter back to the Chief Judge since the case was yet to feature, due to the handicap of the prosecution to bring Otunla before the court of justice". This matter was sent back to the Honorable Chief Judge for reassignment to any of the judges based in Abuja Division for reassignment in view of the special circumstance of this case."

In "accounting fraud: a literature review" Tutino and Merlo (2019) explains the central features of accounting fraud across an assessment of the existing literature by putting the environment and the diverse ways to avoid fraud under a microscope. The study analyses in 5 steps how company governance, ethical behavior, accounting manipulation, detection techniques and forensic accounting are correlated with fraud. After having evaluated the most significant literature on the topic, it emerged that in order to avoid fraudulent behavior in a company; it is significant, typically, to ascertain an ethical education among employees and executives.

This research is primarily anchored on the Ecological Theory (ET). An assessment of several of the well-known accounting frauds may perhaps suggest that several criminal kinds are attracted to business in general and to accounting in particular. Therefore, the fraudulent cases are not pinpointing a general happening in the field, but the effect of the fraudulent actions of the minority of criminal types that have been fascinated to the discipline of accounting. This approach is recognized as the "Lombrosian" view of criminology. But with the Lombrosian Theory (LT) of a physical "criminal type" losing its petition, the ET appears as a more practicable and superior substitute to an explanation of the fraud scheme in accounting and by accountants (Ahmed, 2017). It adopts as a foundation of explanation of company fraud schemes in accounting. It is generally defined as the decline in control of obtainable rules of behavior on individual members of the group. Criminal behavior in the accounting field is to be taken as a pointer of a fundamental social disorganization. Primarily, frail social organization of the discipline of accounting results in criminal behavior. 
Subsequent, with the collective control of the discipline declining because of the broad public unresponsiveness, some accountants are freed from ethical sensitivities and are inclined to corporate fraud. It is then the wide-ranging public's failure to function successfully as an agency of collective control that is the direct cause of corporate fraud, fraudulent financial reporting, and audit failure. Essentially, a number of accountants are freed from ethical sensitivities when social control breaks down or fails to function properly (Ahmed, 2017).

\section{Methodology}

Survey design was used in this work as it can present a much wider reporting and it is quick and cost-effective. Chigo and ljeoma (2017) believed that it offers convenience and can be analyzed with no wasting much time; results generated will be comprehensive and would represent the bigger population. This is for the reason that the work used the perceptions of the respondents in achieving the declared objectives. The populations of this work were accountants and auditors in government organization in Edo, Delta, Enugu and Anambra States. The population consists of 2267 accountants and 654 auditors. 42 government organizations were sampled. 102 auditors (sample A) and 162 (sample B) accountants were sampled in the 4 states. The research instrument used was a structured questionnaire. Sample A was employed in testing hypothesis three while sample B was adopted in testing hypotheses two and three. The data used for analysis are collected through the use of likert scale closed ended structured questionnaire. The data collected were analyzed adopting the P.value percentage and the Chi-Sqaure. Cronbach's Alpha statistical tool was used in determining the reliability. The result revealed a reliability of 0.711 . In determining the sample size for this research, the Osagioduwa and Rejoice (2020) sampling technique was employed to justify the adequacy of the sample size. The formula applied is given as $\mathrm{n}=\mathrm{R} /\left(3+\mathrm{R} \mathrm{e}^{2}\right) \times 100 / 60$ Where $\mathrm{n}=$ Number of samples, $\mathrm{N}=$ Total population, $\mathrm{e}=$ Error tolerance and $3=$ adjusted constant, $100 / 60=$ moderating multiplier.

Sample B determination: $\mathrm{n}=2267 /\left(3+2267 \times 0.05^{2}\right) \times 100 / 60 ; n=2267 /(3+$ $5.6675) \times 1.66666667 ; n=2267 /(8.6675) \times 1.66666667 ; n=2267 / 14.4458333$; $\mathrm{n}=2267 / 14=162$ : (sample size)

Sample A determination: $n=R /\left(3+R e^{2}\right) \times 100 / 60$

Where $\mathrm{n}=$ Number of samples, $\mathrm{N}=$ Total population, $\mathrm{e}=$ Error tolerance and 3 $=$ adjusted constant. $n=654 /\left(3+654 \times 0.05^{2}\right) \times 100 / 60 ; n=654 /(3+1.635) \times$ $1.66666667 ; n=654 /(4.635) \times 1.66666667 ; n=654 / 6.6349999998 ; n=654 / 6$ $=109$

\section{Model Specification \\ Conceptual Model}

FRA\%RED\%=f (PRO\%COR\%ACC\% + DIS\%C\%\%ACC\% + PR\%O\%C\%P\%O\%)

Where:

FRA\%RED\% = fraud control

DIS\%C\%\%ACC\% = dismissal of fraudulent accountant

$P R O \% C O R \% A C C \%$ = prosecution of fraudulent

accountant.

$P R \% O \% C \% P \% O \%=$ prosecution of fraudulent accountant assisting public

officers in perpetrating fraud 


\section{Analytical Model}

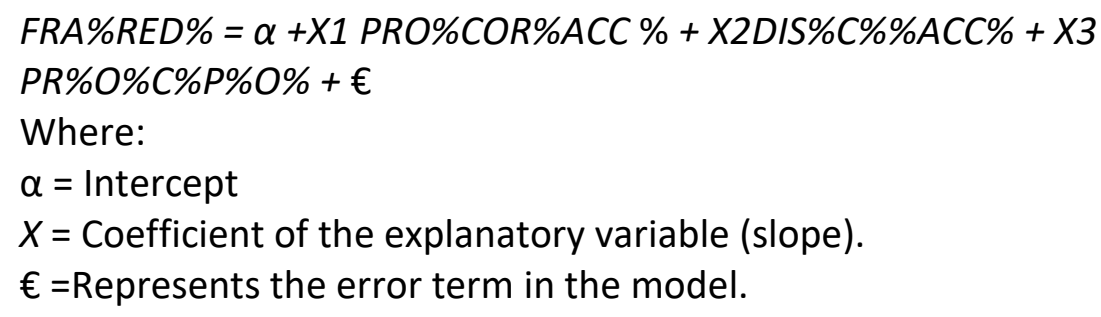

\section{Data Analysis and Presentation}

Table 4.1 professional qualification of respondents

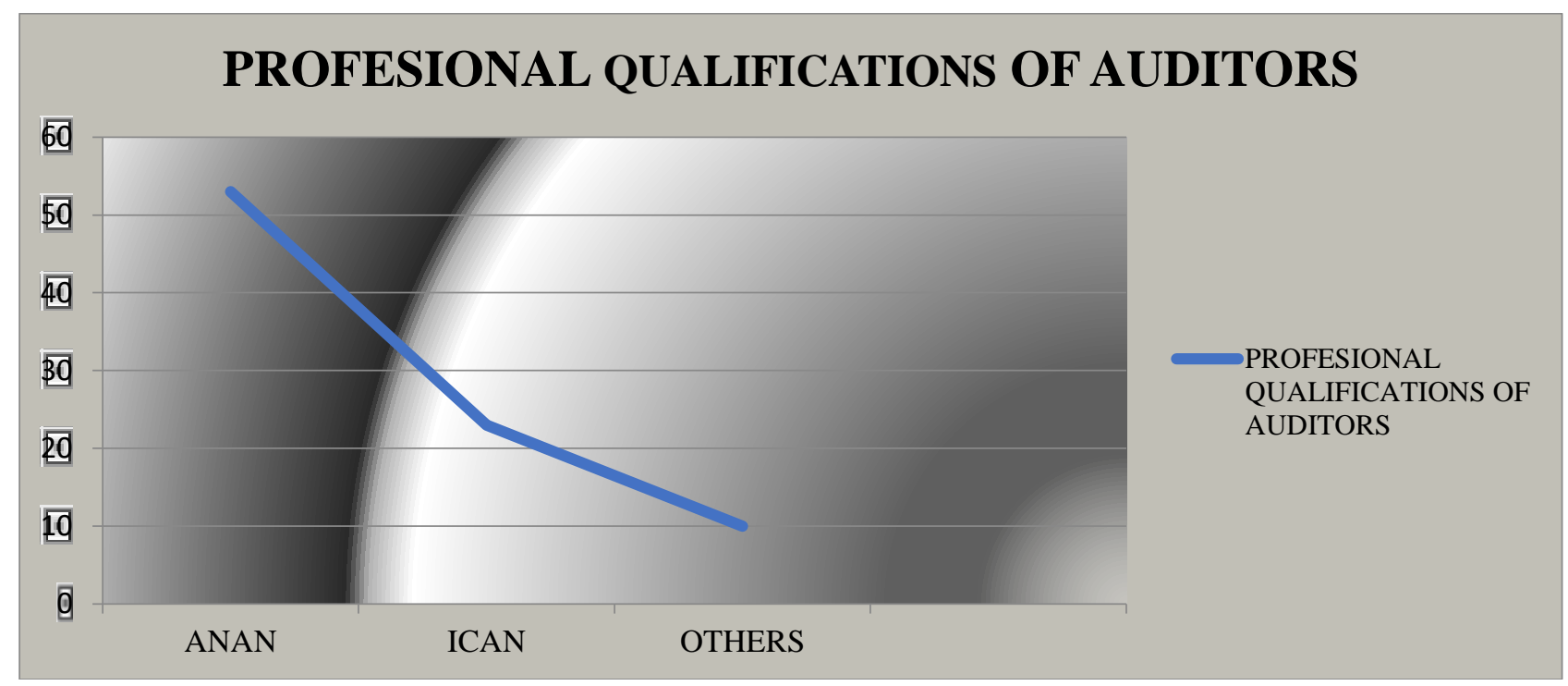

Source (field work)

Table 4.1 reveals the professional qualification of sample B. $53.3333333 \%$ of the respondents are ANAN members. 23.3333 hold ICAN membership while $23.333333 \%$ were members of other professional bodies.

Table 4.2 professional qualification of respondents

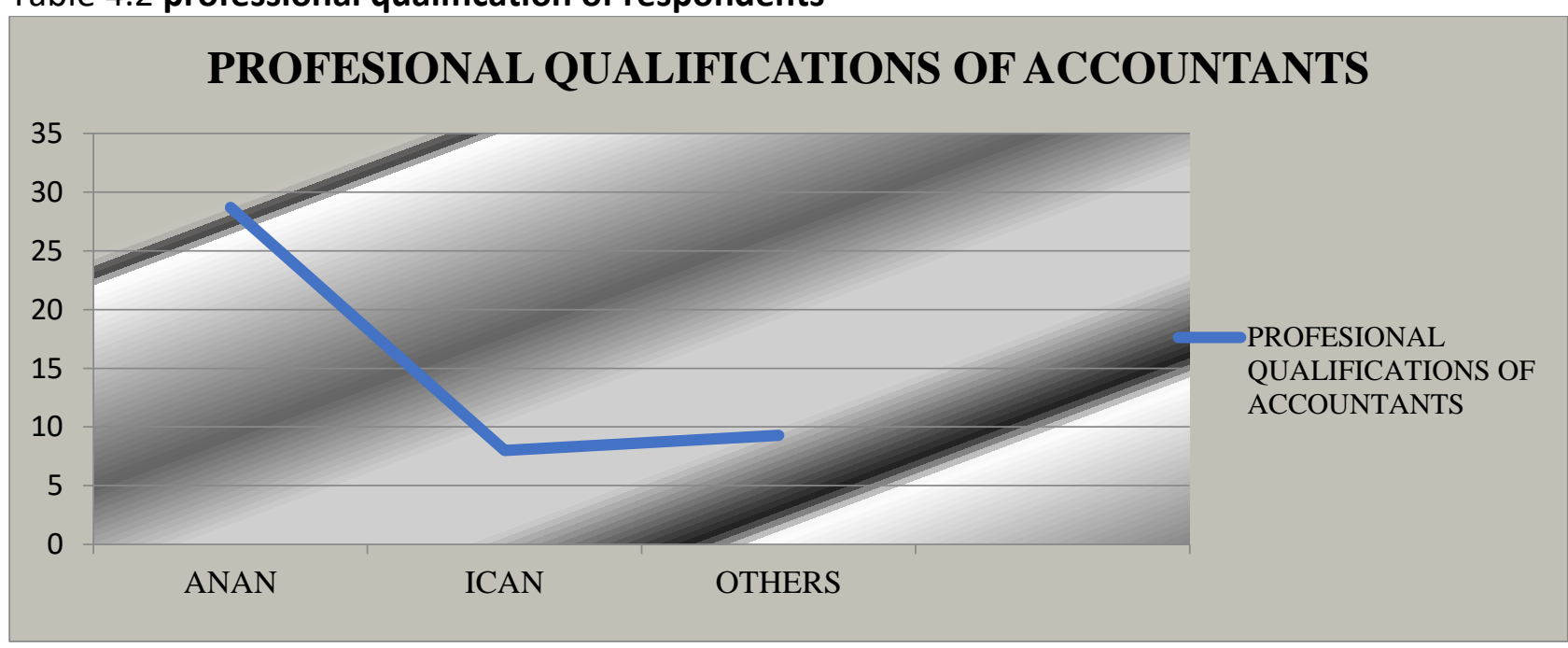

Source (Authors' Extraction)

Finally, $29 \%$ of the total respondents are ANAN members while $8 \%$ of the total respondents are ICAN members. Other qualifications were $9.3 \%$. 


\section{Hypotheses Testing}

Hypothesis one: accountants involved in fraud scheme are prosecuted in the Nigerian public sector.

Table 4.3 Computation of Chi-Square,

\begin{tabular}{|l|l|l|l|l|l|}
\hline Respondent & OI & EI & $($ OI-EI) & $($ OI-EI) & $\Sigma(\mathrm{OI}-\mathrm{EI})^{2} / \mathrm{EI}$ \\
\hline Strongly agree & 51.0 & 32.4 & 18.6 & 345.96 & 10.677777778 \\
\hline Agree & 77.0 & 32.4 & 44.6 & 1989.16 & 61.39382716 \\
\hline Undecided & 16.0 & 32.4 & -16.4 & 268.96 & 8.301 \\
\hline Disagree & 13.0 & 32.4 & -19.4 & 376.36 & 11.61604938 \\
\hline $\begin{array}{l}\text { Strongly } \\
\text { disagree }\end{array}$ & 5.0 & 32.4 & -27.4 & 750.76 & 23.17160 \\
\hline $\begin{array}{l}\mathrm{X} 2=\Sigma(\text { Oi-Ei)2 / } \\
\text { Ei }\end{array}$ & 162.0 & 32.4 & 3.0 & & 115.1595777 \\
\hline
\end{tabular}

Source (field work)

$\mathrm{X}^{2}=\Sigma(\mathrm{Oi}-\mathrm{Ei}) 2 / \mathrm{Ei}$ Where $\mathrm{X}^{2}=$ Chi-square, $\mathrm{Oi}=$ Observed frequency or data, $\mathrm{Ei}=$ Expected frequency or data. Source: Agbadudu (1994.). $E i=162 / 5=32.4$, the cal $X^{2}=115.1595777, X^{2}$ $a k=a=0.05 k=5-1=4 X 20.05,4 X^{2}=9.49$. At $5 \%$ level of significance and 1 degree of freedom, tab $X^{2}=9.49$ while Cal $X^{2}=115.1595777$

Decision Rule: From the above, Cal $X^{2}$ exceeds tab $X^{2}$, (cal $\left.X^{2}>\operatorname{tab} X^{2}\right)$ we will therefore reject the null hypothesis and accept the alternative hypothesis that state that accountants involved in fraud scheme are prosecuted in the Nigerian public sector.

Decision: This means that accountants involved in fraud scheme are prosecuted in the Nigerian public sector.

Hypothesis two: fraudulent accountants working in Nigerian public sector are moderately dismissed from duty due to fraud. 
Table 4.4 P.value Percentages Analysis

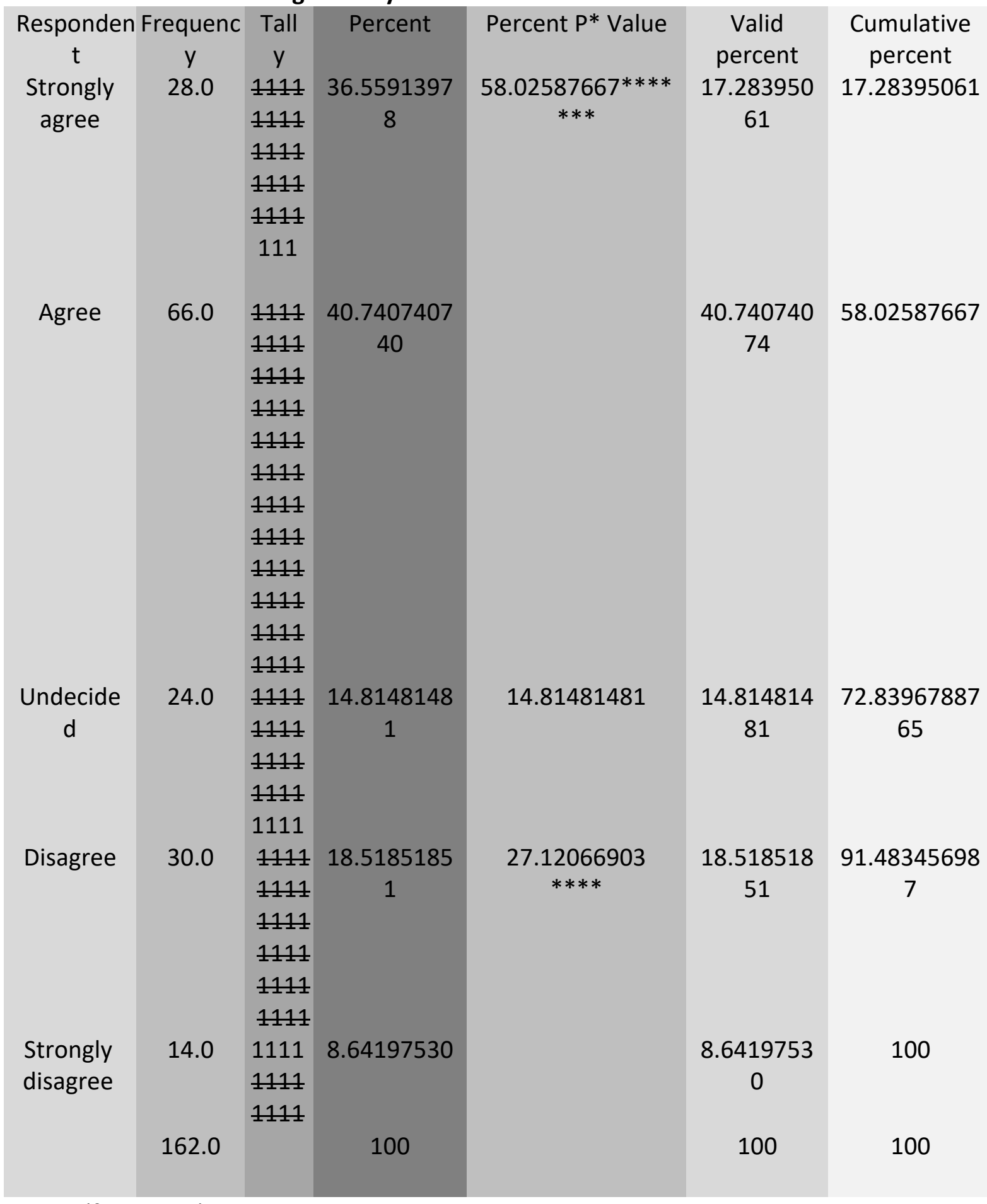

Source (field work)

The percentage responses of the respondents reveal that fraudulent accountants working in Nigerian public sector are moderately dismissed from duty due to fraud. This is the indication of the percentage $p$-value of $58.02587667 * * * * * * *$. This further is an indication that the number of fraudulent accountants working in Nigerian public sector dismissed from duty due to fraud is moderate. $\mathrm{P}$ value of $27.12066903888888^{* * * *}$ show the rate of fraudulent accountants working in Nigerian public sector are not dismissed from duty due to fraud. Though we therefore accept the alternate hypothesis that some fraudulent accountants 
working in Nigerian public sector are dismissed from duty due to fraud and reject the null hypothesis.

Hypothesis three: fraudulent public officers are significantly assisted by accountant in perpetrating fraud in the public sector in Nigeria.

Table 4.5 Computation of Chi-Square

\begin{tabular}{|c|c|c|c|c|c|}
\hline Respondent & $\mathrm{Ol}$ & $\mathrm{El}$ & (OI-EI) & $(\mathrm{OI}-\mathrm{EI})^{2}$ & $\Sigma(\mathrm{OI}-\mathrm{EI})^{2} / \mathrm{EI}$ \\
\hline Strongly agree & 15.0 & 20.4 & -5.4 & 29.16 & 1.429411764 \\
\hline Agree & 37.0 & 20.4 & 16.6 & 275.56 & 13.507843137 \\
\hline Undecided & 19.0 & 20.4 & -1.4 & 1.96 & 0.097512437 \\
\hline Disagree & 24.0 & 20.4 & 3.6 & 12.96 & 0.6352941176 \\
\hline $\begin{array}{l}\text { Strongly } \\
\text { disagree }\end{array}$ & 7.0 & 20.4 & -13.4 & 179.56 & 8.801960784 \\
\hline $\begin{array}{l}X 2=\Sigma(0 \mathrm{i}-\mathrm{Ei}) 2 / \\
\mathrm{Ei}\end{array}$ & 102.0 & 20.4 & 000000 & 000000 & $24.37297654567 * * * * * *$ \\
\hline
\end{tabular}

$\mathrm{X}^{2}=\Sigma$ (Oi-Ei) 2/ Ei Where $\mathrm{X}^{2}=$ Chi-square, $\mathrm{Oi}=$ Observed frequency or data, $\mathrm{Ei}=$ Expected frequency or data. $\mathrm{Ei}=102 / 5=20.4$, the cal $\mathrm{X}^{2}=24.37297654567^{* * * * * *}, \mathrm{X}^{2}$ a $\mathrm{k}=\mathrm{a}=0.05 \mathrm{k}=5-$ $1=4 X^{2} 0.05,4 X^{2}=9.49$. At $5 \%$ level of significance and 1 degree of freedom, tab $X^{2}=9.49$ while Cal $X^{2}=24.37297654567 * * * * * *$.

Decision Rule: From the above, Cal $X^{2}(24.37297654567 * * * * * *)$ exceeds tab $X^{2}$ (9.49) of (cal $X^{2}>\operatorname{tab} X^{2}$ ) we will therefore reject the null hypothesis and accept the alternative hypothesis that state that fraudulent public officers are significantly assisted by accountant in perpetrating fraud in the public sector in Nigeria.

Decision: This connote that the fraudulent public officers are significantly assisted by accountant in perpetrating fraud in the public sector in Nigeria. Fraud can hardly take place in any organization without the knowledge of the accountants.

\section{Summary of Findings, Conclusion and Recommendations}

It was found that accountants involved in fraud scheme are prosecuted in the Nigerian public sector. This is evidence in the prosecution of the Marshal Agency (SMA) accountant of the agency, over an alleged fraud scheme, money laundering and diversion of staffs' remunerations to the tune of N10 million. The accountant was arrested in Sokoto by the EFCC. The DG and accountant's arrest followed a prosecution and a petition mutually signed and sent to the EFCC by thirty-nine (39) members of the agency, alleging that their remunerations for 3 months were being suspended without any explanation. The petitioners additionally alleged that the DG and the accountant refused to pay their remunerations and diverted the money to private use (vanguard, 2019). Furthermore, Wahab (2019) asserted that the EFCC arrested Covenant University accountant for supposedly diverting $\mathrm{N} 180 \mathrm{~m}$ belonging to the tertiary institution. The accountant was prosecuted over an alleged case of embezzling. The diversion of the funds was said to have taken a good number of years before the university discovered his alleged fraud. The Chancellor of the university described the lifestyle of the accountant as riotous and unruly (Wahab, 2019). Accountants in the globa

In the same vein in agreement to the findings, Akinloye (2019) highlighted an accountant in the UK, Sam Kayode, who was prosecuted and sentenced to 9 years in prison for defrauding 
£4.1million. The accountant was sentenced by Woolwich Crown Court in South London for embezzling Haberdashers' Aske's state schools in the United Kingdom. The accountant, who earned $£ 57,000$ in every twelve months, was convicted after being established guilty of $£ 150,000$ and $£ 3.95 m$ theft and fraud respectively. Of the $£ 4.1 \mathrm{~m}$, just $£ 800,000$ was retrieved from him. Described as fraudulent and greedy, the court heard how the accountant lavish the loot on 4 women his wife, a second 'wife' in Nigeria, and two other women in the UK. British prosecutor, James Thacker, noted that the accountant also acquired luxury cars. The accountant was alleged to be secretive, locking himself in his office to work late hours.

In was also found that fraudulent accountants working in Nigerian public sector are moderately dismissed from duty due to fraud. However, the $p$ value of 27.1 is an implication that 27.1 percent of fraudulent accountants go freely without prosecution in the public sector in Nigeria. The rationale for this might be that either the accountants are expert in fraud, high position in government, political god children among others. The accountants are supposed to be professionals in integrity, honesty, due care and diligence, truthfulness, objectivity among other good virtues.

In addition, it was also discovered that fraudulent public officers are significantly assisted by accountant in perpetrating fraud in the public sector in Nigeria. In agreement, John and Perry (1984) noting some areas accountants can assist and also perpetrate fraud in organization. Accountants conceal involvedness and mislead investors, declining and failing firms have resorted to the succeeding misleading reporting practices. (1) advance recognizing of earnings, (2) inappropriately treatment of operating leases as sales, (3) inflated inventory by improper application of the LIFO inventory technique, (4) included fabricated figures in inventories, (5) failed to acknowledge losses via write-offs and allowances, (6) inappropriately capitalized or postponed costs and expenses, (7) including extraordinary gains in operating earnings, (8) overestimated marketable securities, (9) created "sham" year-end transactions to improve reported earnings, and (10) charged their accounting practices to augment earnings without unveiling the changes.

The study therefore concludes that accountants involved in fraud scheme are significantly prosecuted in the Nigerian public sector. In addition, fraudulent accountants working in Nigerian public sector are moderately dismissed from duty due to fraud. Lastly, it was also concluded that fraudulent public officers are significantly assisted by accountant in perpetrating fraud in the public sector in Nigeria.

On the bases of the findings and conclusion, the study therefore recommends that:

1. The accounting professional bodies and accounting standards setting organization nationally and globally, for instances the Institutes of Chartered Accountant of Nigeria (ICAN), ANNA, FRCN, ACCA; ACFE among others should outline active and purposeful prosecution guideline for fraudulent accountants nationally and internationally. Implementation framework should also be followed diligently and strategically.

2. Those Nigerian ethics that some accountants and public office others are beyond prosecution especially when in office should be jettison. All public accountant engaged in fraud should be prosecuted without preferences and partiality. In the same vein, all fraudulent public office holders should be given a fair prosecution in Nigerian public sector. 
3. While a large number of fraudulent government officer are often petitioned, the petition are hardly followed and concluded. It is therefore recommended that all petitions should be concluded and without any political intervention.

4. All fraudulent accountants and public office holders who stole an amount amounting to $\mathrm{N} 2 \mathrm{~m}$ and above should be hanged to death.

\section{References}

Adetula, S. L., \& Amupitan, M. D. (2018). Whistleblowing as a tool for fighting the menace of Fraud, forgery and Corruption in Nigeria. International Journal of Advanced Academic Research, Social and Management Sciences 4(3).

Ahmed, R. B. (2017). The architecture of fraud in the accounting environment. available at: https://www.researchgate.net/publication/320853838

AICPA. (1988). Testifies at RICO Hearings: Support Boucher Proposal," Journal of Accountancy: 82.

AICPA. (2002). Auditing Standards Board, Consideration of fraud in a financial statement audit, American Institute of Certified Public Accountants (AICPA), SAS No. 99.

Akinloye, B. (2019). Nigerian pastor jailed for $£ 4.1 m$ fraud in UK. Punch. Available at http://punchng.com

Albert, A. V., Thomas, W. G., John, G., \& Isabel, M. C. (2006). A guide to forensic accounting Investigation. John Wiley \& Sons, Inc. Hoboken, New Jersey.

Altman, E. I. (1968). Financial ratios, discriminant analysis and the prediction of corporate bankruptcy. Journal of Finance, 23(4), 589-609. https://doi.org/10.1111/j.15406261.1968.tb00843.x

Amat, O., \& Gowthorpe, C. (2004). Creative accounting: Nature, incidence and ethical issues (UPF Working Paper No. 749). Retrieved from: https://ssrn.com/abstract=563364.

American Institute of Certified Public Accountants. (1987). Special Committee on Accountants' Legal Liability, Alternative Dispute Resolution

Amoz, I., \& Hilkiah, J. (1046-616 BC). Dakes Living Bible King James Version. 11king 5:21-27.

Association of Certified Fraud Examiner. (2017). News and analysis on the global fight against fraud 10 Infamous Fraud Cases of the $21^{\text {st }}$ Century. Available from http://www.acfeinsight.com 10-infam.

Association of Certified Fraud Examiners. (2007). Report on the nation occupational fraud and abuse. Huston, Texas.

Association of Certified Fraud Examiners. (2002) Report to the Nation on Occupational Fraud and Abuse (Austin, Tex.: Association of Certified Fraud Examiners, 2002), 6.

Beneish, M. D. (1999). The detection of earnings manipulation. Financial Analysts Journal, 55(5), 24-36. https://doi.org/10.2469/faj.v55.n5.2296

Benford, F. (1938). The Law of anomalous numbers. Proceedings of the American Philosophical Society, 78, 551-572.

Bhasin, M. L. (2016). Contribution of forensic accounting to corporate governance: An exploratory study of an Asian country. International Business Management, 10(4), 479-492.

Bolanle, O. (2014). Whistle blowing and Anti-Corruption Crusade: Evidence from Nigeria. Canadian Social Science, $10(4), 145-154$. 
Choi, J. (2007). Governance structure and administrative corruption in japan: an organization network approach" public administrative review. 67(5), 930-942. Doi:10:1111/j.15406210.2007.00779.x.

Committee of Sponsoring Organizations of the Treadway Commission (COSO) (1987). Report of the National Commission on Fraudulent Financial Reporting 103.

Digabriele, J. A. (2009). Implicational of regulatory prescriptions and audit standards on the evolution of forensic accounting in the audit process. Journal of Applied Accounting Research, 10(2), 109-121. https://doi.org/10.1108/09675420910984673.

EFCC. (2019). 2bn ONSA fraud. Available from: www.efccnigeria.com.

Enofe, A. O., Abilogun, T. O., Omoolorun, A. I., \& Ealiho, E. M. (2017). Bank fraud and preventive measures in Nigeria: An empirical review. International Journal of Academic Research in Business and Social Science, 7(7), 1-12

Enriques, L., \& Volpin, P. (2007). Corporate governance reforms in continental Europe. Journal of Economic Perspectives, 21(1), 117-140. https://doi.org/10.1257/jep.21.1.117

Etuk, I. C. (2011). Evaluation of internal control system of banks in Nigeria. Doctor of Philosophy (PhD) Accounting Dissertation, St. Clements University, 1-32

Evelyn, O. T., \& Oladipupo, A. O. (2020). Minimizing fraud incidences through whistleblowing mechanism. 1st International Conference of Faculty of Management Sciences, University of Benin, Nigeria.

Financial Accounting Standards Board. (1993), Statement of Financial Accounting Standards No. 115, Accounting for Certain Investments in Debt and Equity Securities, par. 6.

Hegazy, S., Sangster, A., \& Kotb, A. (2017). Mapping forensic accounting in UK. Journal of International Accounting, Auditing and Taxation, 28, 43-56.

https://doi.org/10.1016/j.intaccaudtax.2016.12.004

John, M. F., \& Perry, L. G. (1984). Policing Financial Disclosure Fraud: the SEC's Top Priority," Journal of Accountancy: 59

Jones, M. J. (2011). Creative accounting, fraud and international accounting scandals. Hoboken: Wiley.

Joseph, T. W. (2002) "Lapping It Up: A Skimming Method Doomed to Failure over Time," Journal of Accountancy, 73-75.

Kolar, I., \& Zdolsek, D. (2013). Perceptions of forensic accounting related to the investigations of corporate criminal offence. Journal of Criminal Investigation, 64(2), 182-194.

Osagioduwa, L. O. (2019). The effectiveness of the whistle blowing policy in combating corruption in the Nigerian public sector. Global Journal of Arts Humanities and Social Science. 7 (10), 77-98.

Osagioduwa, L. O. (2019a). The effectiveness of the whistle blowing policy in combating corruption in the Nigerian public sector. Global Journal of Arts Humanities and Social Science. 7 (10), 77-98.

Osagioduwa, L. O., \& Ohidoa, T. (2020, January). Corruption Detection and Exposure, an Expected Role of Public Auditors: A Case of the Nigerian Public Sector. A. O. Oladipupo (chair). $1^{\text {st }}$ international conference of the Faculty of Management Science of the University of Benin, Edo State Nigeria.

Osagioduwa, L. O. (2019b). Treasury single account effectiveness on corruption control and public organizations efficient administration in Nigeria. International Journal of Management Studies and Social Sciences. 
Quirin, J. J., \& O'Bryan, D. W. (2014). The mobile home monster: A forensic case in the use of public records to locate assets. Issues in Accounting Education, 29(2), 371-378. https://doi.org/10.2308/iace-50616.

Richard, S. B., \& Douglas, C. B. (1987). Arbitration: An Option for Resolving Claims Against CPAs," Journal of Accountancy: 124.

Ali, S. Z., Butt, S. A., \& Bin Tariq, Y. (2011). Use or abuse of creative accounting techniques. International Journal of Trade, Economics and Finance, 2(6), 531-536.

Soni, D. (2020). Church accountant jailed for 18 years over N15.5m theft. Vanguard.

Sorensen, D. P., \& Miller, S. E. (2017). Financial accounting scandals and the reform of corporate governance in the United States and in Italy. Corporate Governance, 17(1), 77-88. https://doi.org/10.1108/CG-05-2016-0125.

Stevens, H. C. (1985). "Professional Liability: The Situation Worsens," Journal of Accountancy: 66.

Transparency International. (2012). Transparency international corruption perception index 2012. Retrieved from http://www.ey.com/Publication/vwLUAssets/2012_TI_ CPI/\$FILE/2012\%20TI\%20CPI.

Tutino, M., \& Merlo, M. (2019). Accounting fraud: A literature review. Risk Governance and Control: Financial Markets \& Institutions, 9(1), 8-25. http://doi.org/10.22495/rgcv9i1p1

Vanguard. (2019). EFCC arrects Sokoto Marshalls DG, Accountant over alleged fraud. Available from www.vanguardr.com

Virgina, B. (2019). Top accounting cases scandals in 2018. Accounting age. Available from http://www.accountancyage.com.

Wahab, B. (2019). Covenant university accountant arrested for alleged stealing $\mathrm{N} 180 \mathrm{~m}$. Pulse. Available from www.pulse.ng

Wikipedia, (nd). Available from http://en.m.wikipedia.org/wiki/bidrigging. 